\title{
PRODUCT-BASED LEARNING MODEL THROUGH THE ALIGNMENT OF MECHANICAL ENGINEERING COMPETENCIES WITH INDUSTRY
}

\author{
Heri Yudiono ${ }^{1, ~ *}$, Sonika Maulana², M. Burhan Rubai Wijaya ${ }^{3}$, Rahmat Aprianto $^{4}$, Karsan $^{5}$ \\ 1,2,3,4,5 Department of Mechanical Engineering, Universitas Negeri Semarang, Jl. Taman Siswa Sekaran, Gunungpati \\ Semarang 50229, Indonesia \\ E-mail: heri_yudiono@mail.unnes.ac.id * \\ *Corresponding Author
}

\begin{abstract}
The alignment of the competencies in the industry with vocational school is crucial to develop the graduate skills to comply with industry needs. Competency alignment can be performed through an innovative learning model by integrating the industrial activities into learning activities. This study assessed the feasibility of the product-based learning model to improve the mechanical engineering competence by aligning competencies of the vocational school with industry. This study used experimental research with one group pretest-posttest design. The study employed data analysis consisting of the T-test and the feasibility testing of the model. The effectiveness testing of the model was performed by comparing student's achievement before and after using the learning model. The feasibility test was conducted on 39 students participating in the subject of Machining Process II. The results of the study revealed that there were significant differences in mechanical engineering competencies before and after using the learning model. These results indicated that the industry and stakeholders need to be involved in each stage of learning.
\end{abstract}

Keywords: industrial competence, mechanical engineering, production-based learning

\section{INTRODUCTION}

The learning process for students of Mechanical Engineering is ideally developed based on the competencies required by the industries. This is achieved by aligning the curriculum of the school with the industry. Alignment of the curriculum is carried out by using the appropriate framework for effective, efficient, reliable, and appropriate implementation in the learning process. It is carried out through curriculum alignment with the industry. Curriculum alignment uses the right framework so it is effective, efficient, reliable, and accurate in learning [1]. The curriculum and learning experience of students must be relevant to the needs of industry, where the level of relevance of school curriculum with industry can be achieved with the involvement of stakeholders [2].

The curriculum alignment should be carried out constructively by considering the achievement of learning objectives [3]. Curriculum alignment is required for learning achievement, because the curriculum is dynamic, developable, visible, assessment and improvement of learning [4]. Curriculum and teaching development are influenced by changes in policies, novel technologies, and globalization [5]. However, the teacher is always the key in changing the implementation of learning. Teachers play a significant role in encouraging students' learning innovations to solve problems and transfer what has been learned to daily life [6].

Accuracy in the selection of the learning model is expected to improve the learning experience and competence of the students after completing the course. Educational success is determined in selecting and implementing the appropriate learning model [3], [7]. The production-based learning concept becomes one of the leading paradigms in vocational education, in which the learning process integrates academic-based learning with the activities of the industry. This learning aims to help improve the experience of technical learning in schools and direct student learning practices under industrial conditions [4], [8]. Production-based learning can improve and 
facilitate the process of students' learning experience to improve their skills, the quality of teaching, and learning outcomes [5], [9]. Practicum learning with projects from the industry could effectively enhance the experience and learning outcomes for the milling techniques [6], [10].

Product-based learning facilitates students to be actively involved in the learning process and subsequently improve their communication and collaboration skills. Various projects require a lot of competencies from various scientific disciplines. Therefore, students can improve their knowledge, problem-solving skills, and team skills with other types of practice [7], [11].

The process of product-based learning is integrated into the production process, where students are given a learning experience in a contextual situation based on the flow of the industrial work starting from orders based on planning, implementation, and evaluation of products or quality control. The learning process is designed to focus on relevant competencies by expanding the adequacy of competency models [8], [12]. The benefits of collaborative learning projects encourage students to work together to solve problems and complex technological development, and students to think critically. Project assignments by students are closer to professional reality, directed at the application of knowledge, involving many disciplines to support the project, self-direction is stronger [9], [13].

Product-based learning has been proven to be an important model for educating students and professionals about the principles of production management [10], [14]. The contribution of product-based learning to learners' self-development and competence has been widely recognized [11], [15]. The implementation of product-based learning consists of the stages such as: conceive, design, implement and operate [12], [16].

This research was conducted by focusing on the feasibility of a product-based learning model through the alignment of mechanical engineering competencies with industry. The implementation of product-based learning is expected to improve learning experiences and develop the competencies of mechanical engineering students. This study is also expected to produce alternative models of product-based learning through alignment of competencies with industry.

Several studies related to project learning have shown that teaching and learning activities are still oriented to the principles of production process management and student selfdevelopment. However, no research analyzes project learning that focuses on industrial products to develop student learning experiences. Based on this gap, this study will focus on the industrial project learning model through alignment of competencies with industry.

\section{METHOD}

The research approach used experimental research with one group pretest-posttest design. The study was conducted by compare learning achievements before and after using a productbased learning model. It was an experimental study using one group pretest-posttest. The study employed data analysis consisting of the T-test and the feasibility testing of the model. The T-test was used to test the differences and feasibility of the model by comparing conditions before and after the implementation of product-based learning through the alignment of the competencies with industry. The data were gathered by using competency test sheets for lathing and milling competencies. The feasibility test was conducted on 39 students participating in the subject of the Machining Process Practicum. The research subjects already had basic mechanical competencies and passed the first Machining Process subject.

The collection of research data used achievement tests in grinding machining, lathe machining, and milling machining. There were 25 items in the achievement test. Testing the 
competency test sheet using validity and reliability testing before being used to collect research data. The test used IBM SPSS Statistic 21. The results of the calculation showed that 25 test items were valid for use in research data collection because the correlation coefficient $r$ count was greater than the rtable with a significance level of $5 \%$ of 0.361 . While the results of reliability calculations show that $r_{\text {count }}$ is .836 greater than the r table with a 5\% significance level of .361, thus the competency test sheet is reliable. Reliability test results are shown in Table 1 .

Table 1. Reliability Test of the Competency Test Sheet

\begin{tabular}{cc}
\hline Cronbach's Alpha & N of Items \\
\hline .836 & 25 \\
\hline
\end{tabular}

Data analysis used the T-test and the effectiveness of learning models with data analysis application. T-test was used to determine differences in students' competencies before and after using the learning model. The model's effectiveness assessment was carried out by comparing learning achievements before and after using the learning model. Interpretation of results of the feasibility study in product-based learning management model through productive competencies alignment with industry was shown in Table 2 .

Table 2. Interpretation of Feasibility Coefficient

\begin{tabular}{cc}
\hline $\begin{array}{c}\text { Feasibility } \\
\text { Coefficient } \\
(\%)\end{array}$ & Feasibility Level \\
\hline 0 to 20 & Very Low \\
21 to 40 & Low \\
41 to 60 & Enough \\
61 to 80 & High \\
81 to 100 & Very High \\
\hline
\end{tabular}

\section{RESULTS AND DISCUSSION}

The product-based learning model through the alignment of productive competencies with industry is developed by adopted the CDIO model of Pee and Leong. This learning model was developed into five stages including alignment, conceive, design, implementation, and evaluation. The model is presented in Figure 1.

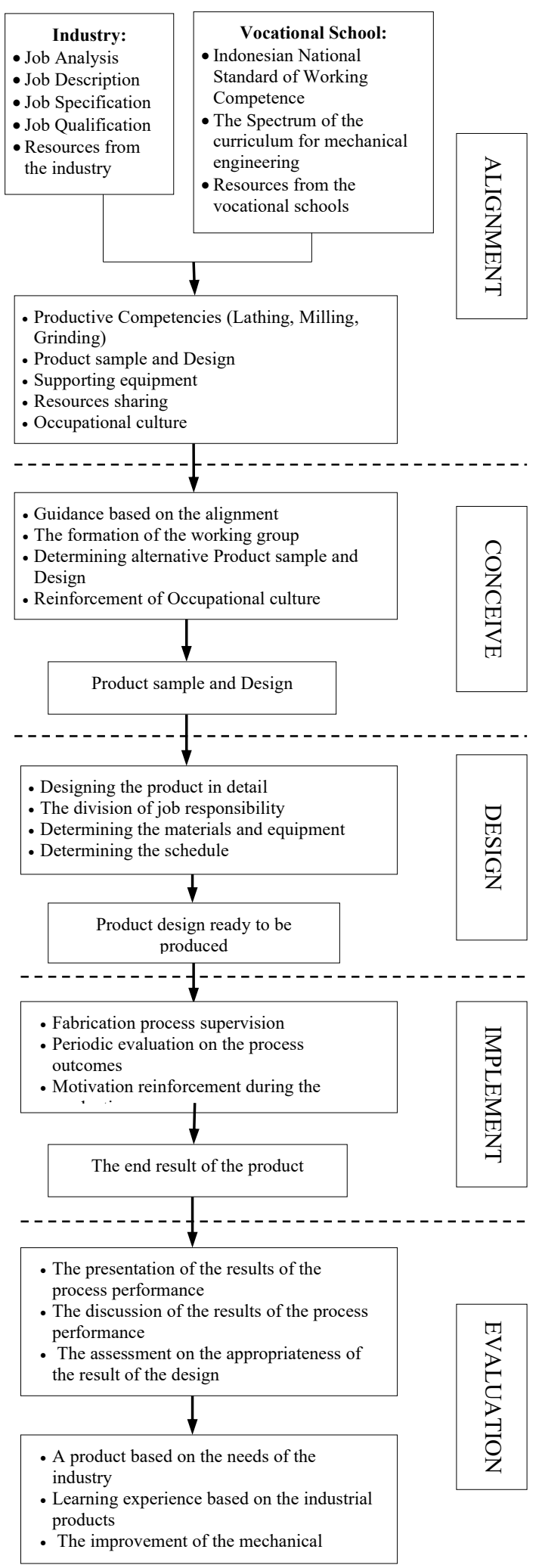

Figure 1. The Management of Product-Based Learning through Alignment of Productive Mechanical Engineering Competence with the Industry 
The alignment stage is the initial stage where educators conduct alignment of competencies with partners from industries to obtain job analysis information, job description, job qualification, and industry-owned resources. Results of the alignment are in the form of productive competence (grinding, milling, and lathe), sample products, and engine component design of rotogravure, as well as resource sharing.

In the conceive stage, it is carried out through understanding the learning plan, informing the results of competency alignment, the formation of group work, determining products, and the reinforcement of the occupational culture. The formation of working groups was chosen randomly based on the scope of competence at each product and the design of machine components. The selection of members in each working group was random and each group has an average of 4 students. The results of the conceive stage are the sample products and product designs that will be manufactured.

The design stage was carried out by designing the detailed product designs, determining materials and equipment, division of work responsibilities, and determining activity schedules. The results of the design phase were designs that are ready to be produced.

The implementation stage was carried out by assisting the production process, evaluating the achievement of the process periodically, and reinforcing the motivation of the fabrication process. The results of the implementation stage were the final product of the learning process.

The evaluation stage was conducted through presentation and discussion of the results of the process performance, as well as the assessment on the appropriateness of the final product of learning. Besides, the end result of this learning process is the final product of the learning process based on the needs of the industry, the improvement of the mechanical engineering competencies, and industrial product-based learning experiences.

The feasibility study was carried out to test the final model of product-based learning management by aligning productive competencies with industry. The feasibility study design was carried out using dependent ttests for paired data, where each subject was measured or intervened twice, both before and after conducting product-based learning through aligning productive competencies with industry. The subjects of the feasibility study were 39 students participating in the subject of Machining Process I. The results of a feasibility study of a product-based learning management model through the alignment of productive competencies with the industry are shown in Table 3.

Table 3 reveals that the final mean score after conducting production-based learning through alignment of mechanical engineering competencies with industry is 84.51 . The mean score has increased by $46.62 \%$ compared to the mean score before the intervention which was 54.64. The result indicates that the productbased learning model through effective competency alignment can improve mechanical engineering competency.

The results of the t-test also indicate that the sig. value $=0.000<0.05(\mathrm{sig}<0.05)$ which means that there are significant differences before and after the implementation of the production-based learning model through alignment of the mechanical engineering competence with industry. The results of the ttest are presented in Table 4.

The product-based learning model through the alignment of competencies with industries is feasible to improve students' competency and learning experiences. The learning model is effective since the implementation was preceded by the alignment of the competencies required by industry and the accuracy in determining learning activities. The competency alignment is performed to minimize the competency gaps and develop 
students' competency. It was carried out by conducting workplace-oriented educational programs [13], [17]. The competency alignment in the product-based learning model was performed constructively, students can construct meaning through relevant learning activities. The competency alignment does not only refer to the desired results of teaching about content but to the level of understanding that students must achieve [14], [18].

Table 3. Feasibility Test of Product-Based Learning Management Model through Aligning

\begin{tabular}{|c|c|c|}
\hline $\begin{array}{c}\text { No } \\
\text { Respondent }\end{array}$ & $\begin{array}{l}\text { Score of } \\
\text { Pre-Test }\end{array}$ & $\begin{array}{c}\text { Score of } \\
\text { Post Test }\end{array}$ \\
\hline 1 & 44 & 84 \\
\hline 2 & 48 & 88 \\
\hline 3 & 40 & 64 \\
\hline 4 & 44 & 76 \\
\hline 5 & 52 & 76 \\
\hline 6 & 56 & 88 \\
\hline 7 & 24 & 52 \\
\hline 8 & 48 & 92 \\
\hline 9 & 20 & 88 \\
\hline 10 & 84 & 100 \\
\hline 11 & 40 & 80 \\
\hline 12 & 48 & 88 \\
\hline 13 & 56 & 80 \\
\hline 14 & 60 & 84 \\
\hline 15 & 32 & 76 \\
\hline 16 & 36 & 72 \\
\hline 17 & 52 & 80 \\
\hline 18 & 92 & 100 \\
\hline 19 & 36 & 72 \\
\hline 20 & 60 & 84 \\
\hline 21 & 52 & 84 \\
\hline 22 & 76 & 96 \\
\hline 23 & 60 & 88 \\
\hline 24 & 68 & 88 \\
\hline 25 & 32 & 72 \\
\hline 26 & 84 & 92 \\
\hline 27 & 84 & 84 \\
\hline 28 & 56 & 72 \\
\hline 29 & 72 & 96 \\
\hline 30 & 64 & 84 \\
\hline 31 & 76 & 88 \\
\hline 32 & 60 & 96 \\
\hline 33 & 72 & 92 \\
\hline 34 & 72 & 96 \\
\hline 35 & 68 & 96 \\
\hline 36 & 48 & 84 \\
\hline 37 & 68 & 88 \\
\hline 38 & 92 & 88 \\
\hline 39 & 72 & 88 \\
\hline
\end{tabular}

Table 4. T-Test Results

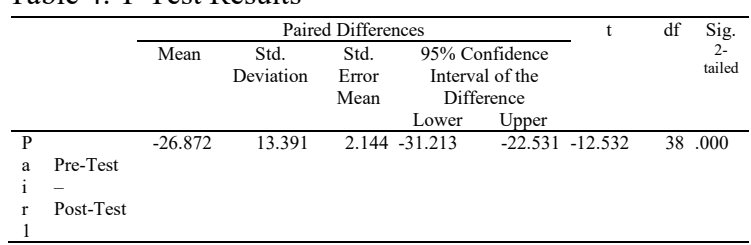

The learning model is also effective because it has the characteristics of conducting the competency alignment with the industry with a clear framework and the learning process is conducted by integrating the industrial activities into the academic activities of the students. The effectiveness of learning can be seen from the involvement of students in learning with self-motivation to achieve the desired learning outcomes, the improvement of the teaching and learning atmosphere, the implementation of learning is performed through reflective teaching, and increasing the teaching ability of teachers.

Industry-based learning frameworks and approaches are needed to measure the initial skills of graduate competencies required by the industry. This learning approach can be an important instrument to identify and assess the skills gap of graduates that relevant to the industry [19]. The alignment framework updates the teacher competency profile and develops student competencies. Competency development encourages teachers to change teaching strategies that appropriate to their level of competence [20]. Competency alignment not only adjusts the requirements needed by industry and national frameworks but how alignment can adapt students' knowledge, skills, and behavior in real life later [21].

\section{CONCLUSION}

This study concluded that the assessment on the feasibility of the product - based learning model by the competency alignment with the industry productive competence are as follows: (1) there is a significant difference in the mechanical engineering competence before and after the implementation of the product - based learning model by the competency alignment 
with the industry productive competence; and (2) the product - based learning model is feasible to improve the students' mechanical engineering competence and learning experiences. It is possible to enhance students' competency and learning environments because it was followed by the matching of industryrequired competencies and the accuracy in determining learning activities. This was an important step to identify and assess the skills gap between students and the industry. It indicates that the industry and stakeholders need to be involved in each stage of learning.

\section{ACKNOWLEDGMENT}

This study was supported by Universitas Negeri Semarang, Indonesia which facilitates this study in implementing the Lecturer Assignment Program in Schools or Program Penugasan Dosen di Sekolah (PDS) through the learning process and research data collection.

\section{REFERENCES}

[1] H. Yudiono, S. Soesanto, and H. Haryono, "An industrial competencybased curriculum alignment model," World Trans. Eng. Technol. Educ., vol. 16, no. 1, pp. 18-22, 2018.

[2] C. R. Finch and J. R. Crunkilton, Curriculum Development in Vocational and Technical Education: Planning, Content, and Implementation. Boston: Allyn and Bacon, Inc., 1979.

[3] K.-A. L. Kuhn and S. R. Rundle-Thiele, "Curriculum alignment: exploring student perception of learning achievement measures," Int. J. Teach. Learn. High. Educ., vol. 21, no. 3, pp. 351-361, 2009.

[4] L.-W. Meij and S. Merx, "Improving curriculum alignment and achieving learning goals by making the curriculum visible," Int. J. Acad. Dev., vol. 23, no. 3, pp. 219-231, 2018, doi: 10.1080/1360144X.2018.1462187.
[5] H. Aydin, B. Ozfidan, and D. Carothers, "Meeting the challenges of curriculum and instruction in school settings in the united states," J. Soc. Stud. Educ. Res., vol. 8, no. 3, pp. 76-92, 2017.

[6] C. L. Chiang and H. Lee, "The effect of project-based learning on learning motivation and problem-solving ability of vocational high school students," Int. J. Inf. Educ. Technol., vol. 6, no. 9, 2016.

[7] K. Asfani, H. Suswanto, and A.-P. Wibawa, "Influential factors of students' competence," World Trans. Eng. Technol. Educ., vol. 14, no. 3, 2016.

[8] L. Rentzos, D. Mavrikios, D. Mourtzis, G. Chryssolouris, and M. Doukas, "Integrating manufacturing education with industrial practice using teaching factory paradigm," Procedia CIRP, vol. 17, pp. 189-194, 2014, doi: 10.1016/j.procir.2014.01.126.

[9] J. Uziak, M. T. Oladiran, M. Eisenberg, and C. Scheffer, "International team approach to project-oriented problembased learning in design," World Trans. Eng. Technol. Educ., vol. 8, no. 2, pp. 137-144, 2010.

[10] H. Yudiono, W. Sumbodo, Salim, and R. Setiadi, "Improving the milling machine competency learning outcomes through industrial project-based learning for vocational school students," J. Pendidik. Vokasi, vol. 9, no. 2, pp. 151-160, 2019, doi: 10.21831/jpv.v9i2.23686.

[11] A. Mitchell, S. Petter, and A. L. Harris, "Learning by doing: twenty successful active learning exercise for information systems courses," J. Inf. Technol. Educ. Innov. Pract., vol. 16, pp. 21-26, 2017.

[12] L. C.Müller-Frommeyer, S. C. Aymans, C. Bargmanna, S. Kauffelda, and C. Herrmann, "Introducing competency models as a tool for holistic competency development in learning factories: Challenges, example and future application," Procedia Manuf., vol. 9, 
pp. $\quad 307-314, \quad 2017, \quad$ doi: 10.1016/j.promfg.2017.04.015.

[13] J. E. Mills and D. Treagust, "Is problem based or project based learning the answer?," Australas. J. Eng. Educ., vol. 4, pp. 1-16, 2003, [Online]. Available: http://www.aaee.com.au/journal $/ 2003 / \mathrm{m}$ ills treagust 03 .pdf.

[14] S. Erola, A. Jägerab, P. Holda, K. Ott, and W. Sihn, "Tangible industry 4.0: a scenario-based approach to learning for the future of production," Procedia CIRP, vol. 54, pp. 13-18, 2016, doi: 10.1016/j.procir.2016.03.162.

[15] J. Lasauskiene and A. Rauduvaite, "Project-based learning at university: teaching experiences of lecturers," Soc. Behav. Sci., vol. 197, no. July, pp. 788-792, 2015, doi: 10.1016/j.sbspro.2015.07.182.

[16] S. H. Pee and H. Liong, "Implementing project based learning using CDIO concepts," 2005.

[17] E. Pang, M. Wong, C. . Leung, and J. Coombes, "Competencies for fresh graduates' success at work: Perspectives of employers," Ind. High. Educ., vol. 33, no. 1, pp. 55-65, 2019, doi: $10.1177 / 0950422218792333$.
[18] S. Caruana and M. Mcpherson, "A constructive alignment approach for assessing essential cultural soft skills in tourism," Procedia - Soc. Behav. Sci., vol. 191, pp. 6-11, 2015, doi: 10.1016/j.sbspro.2015.04.404.

[19] A. Azevedoa, G. Apfelthaler, and D. Hursta, "Competency development in business graduates: An industry-driven approach for examining the alignment of undergraduate business education with industry requirements," Int. J. Manag. Educ., vol. 10, no. 1, pp. 12-28, 2012, doi: 10.1016/j.ijme.2012.02.002.

[20] F. Caena and C. Redecker, "Aligning teacher competence frameworks to $21 \mathrm{st}$ century challenges: The case for the European Digital Competence Framework for Educators ( Digcompedu)," Eur. J. Educ. Stud., vol. 54, no. 3, 2019, doi: 10.1111/ejed.12345.

[21] N. Saad and A. M. Syed, "Alignment of undergraduate business student's competencies with Saudi market requirements," Int. J. Manag. Educ., vol. 12, no. 3, pp. 252-262, 2018, doi: 10.1504/IJMIE.2018.10012325. 